\title{
Effect of Microwave Treatment on the Wood Structure of Norway Spruce and Radiata Pine
}

\author{
Nasko Terziev, ${ }^{\mathrm{a}, *}$ Geoffrey Daniel, ${ }^{\mathrm{a}}$ Grigori Torgovnikov, ${ }^{\mathrm{b}}$ and Peter Vinden ${ }^{\mathrm{b}}$ \\ Low permeability of many wood species causes problems during timber \\ manufacturing, including long drying times, material losses after drying, and \\ expensive drying processes. Impregnating low permeability timber with \\ preservatives and resins is extremely difficult. In the pulp and paper industry, \\ use of low permeability wood results in shallow chemical penetration, and it \\ requires the use of small-sized chips, high chemical usage, and high-energy \\ consumption. Microwave (MW) wood modification technology can provide \\ solutions to many of these problems. The wood structural changes in \\ Norway spruce and radiata pine after MW modification with 0.922 and 2.45 \\ $\mathrm{GHz}$ of were investigated. High intensity MW application (specific MW power \\ 22 to $25 \mathrm{~W} / \mathrm{cm}^{3}$, applied energy 79 to $102 \mathrm{kWh} / \mathrm{m}^{3}$ ) to moist wood caused \\ the following wood structural changes: pit opening and pit membrane \\ rupture; middle lamella weakening and rupture; and ray cell wall destruction \\ and check (voids) formation mainly in the radial-longitudinal plane caused \\ by the destruction of rays and weak middle lamella regions. Microwave \\ destruction of different wood structure elements provided a significant \\ increase in wood permeability for liquids and gases. Knowledge of the \\ effects of MW treatment to the wood structure elements allows assessment \\ of opportunities for the use of microwave irradiation in wood technology.
}

Keywords: Microwave treatments; Norway spruce; Radiata pine; Wood microstructure; Wood permeability

Contact information: a: Department of Forest Biomaterials and Technology/Wood Science, Swedish University of Agricultural Sciences Box 7008, Uppsala, Sweden; b: School of Ecosystem and Forest Science, University of Melbourne, 4 Water Street, Creswick, Victoria 3363, Australia;

*Corresponding author: nasko.terziev@slu.se

\section{INTRODUCTION}

Although studies on the interaction between wood and microwaves (MW) to understand the physical processes of heating and drying of wood have been carried out since the 1950's, the technique has not found wide practical applications. Comprehensive studies in the area include those of Torgovnikov (1993), Perre and Turner (1999, 2004), and Zhao and Turner (2000). The two main technological applications of MW energy on wood are defined as MW drying and MW treatments to increase wood permeability.

Hansson (2007) completed a comprehensive literature review on MW applications for wood drying. Drying methods for industrial processing based on high frequency (HF) electromagnetic fields include microwaves (MW), a combination of vacuum and MW (Leiker and Adamska 2004), or radio frequency (RF) and vacuum (Avramidis et al. 1994; Avramidis and Zwick 1994). An RF drying system creates an alternating electric field between two electrodes. Frequencies of 13.56, 27.12, and 40.68 $\mathrm{MHz}$ corresponding to wavelengths of 22.1, 11.1, and $7.4 \mathrm{~m}$ were used because shorter wavelengths cannot penetrate deeply into the wood material. The main problem in using the MW technique in wood drying is the non-uniform MW field. In order to reduce 
problems of uneven field distribution and power intensity, an industrial-scale online microwave drier for wood components has been adapted for wood (Antti 1999; Antti and Perré 1999) to achieve a uniform heating of the load in order to prevent stress development since too high-energy absorption causes steam expansion resulting in checks. Oloyede and Groombridge (2000) demonstrated that microwave heating reduced the strength of dried wood by $60 \%$. Torgovnikov and Vinden (2000) used the steam expansion caused by microwaves of high intensity to modify selected hardwoods by increasing their permeability but also revealed a decrease of wood strength.

According to Torgovnikov and Vinden (2000), MW processing of heartwood of radiata pine, Douglas fir, and Sitka spruce species using 69 to $111 \mathrm{kWh} / \mathrm{m}^{3}$ energy facilitates the uptake of water-based preservatives by a factor of 2.9 to 5.3 compared with control timber. Refractory hardwood species (such as messmate, yellow stringybark, and blue gum) show an increase of water-based preservative uptake by a factor ranging from 8 to 14 times following microwave modification using an applied MW energy of 158 to 236 $\mathrm{kWh} / \mathrm{m}^{3}$. Very few studies concerning MW treatment of other species are available. Experiments with the MW processing of Norway spruce (Picea abies) demonstrated a significant increase in the uptake of a $2 \%$ copper-based preservative after wood modification by $2.45 \mathrm{GHz}$ MW frequency and energy greater than $50 \mathrm{kWh} / \mathrm{m}^{3}$ (Treu and Gjølsjø 2008). Larch (Larix olgensis) wood modification by applying intensive MW irradiation (Liu Hong-Hai et al. 2005) showed a 2.5- to 3.3-fold increase in water uptake compared with untreated wood while the MOE and MOR remain practically unchanged. Recently Terziev et al. (2019, unpublished results) demonstrated a theoretical model intended for selective opening of the bordered pits in softwoods by strictly defined MW frequencies, thus retaining the mechanical properties of wood unchanged.

Torgovnikov and Vinden (2009) have described structural changes in wood after MW modification, their effect on wood properties, and the process parameters required for different degrees of wood modification. Experiments with hardwood species such as. blue gum (Eucalyptus globulus), shining gum (Eucalyptus nitens), stringybark (Eucalyptus muelleriana), messmate (Eucalyptus obliqua), paulownia (Paulownia elongata), and radiata pine (Pinus radiata) heartwood showed that full cross section preservative penetration can be achieved using the MW approach.

The development of novel wood-based materials and technologies is important from both scientific and industrial points of view. The main challenge in the pulp technology is to intensify the processes and reduce energy consumption. MW technology has been successfully used in trials for the pretreatment of chips for chemical pulping (Scott et al. 2002; Compere 2006; USDE 2006, 2007). The advantages (USDE 2006, 2007) of the treatments included improved yield and throughput (40\%), reduction of chemical use (40\%), and reduction of wood losses associated with oversized chips as well as energy savings due to natural gas reduction (40\%). Another branch of MW utilisation include novel treatments, e.g., initial MW radiation can facilitate the chemical-mechanical defibrillation of wood for subsequent development of new wood-based materials with superior properties (e.g., Song et al. 2018; Li et al. 2019).

The rupture of wood structure elements reduces the strength properties of wood, which is an advantage in many cases when solid wood is converted into chips and fibres in the pulp, chipboard and fibreboard industries. When intense microwave (MW) power is applied to moist wood the internal water content heats rapidly to the boiling point, generating steam pressure within the wood cells. As the pressure increases, the pressure gradients rupture the weakest elements of the wood structure, thereby increasing wood 
permeability for liquids and gases. Increasing MW intensity increases the level of wood modification, consequently increasing wood permeability. Experiments have shown that increasing the level of applied MW power leads to temperatures as high as $158{ }^{\circ} \mathrm{C}$ inside solid wood, which develops steam pressure up to 6 bar. With this process, it is possible to rupture certain wood structure elements and form various sized cavities in both the radial and longitudinal planes increasing porosity and wood permeability in all directions (Torgovnikov and Vinden 2009). Such wood modification requires applied MW energy levels from 250 up to $1200 \mathrm{MJ} / \mathrm{m}^{3}$ depending on the wood species physical properties.

A demonstration of the MW treatment effects on the wood microstructure can explain eventual improvement of wood permeability, reduction of its mechanical performance and demonstrate new paths for further modification of wood materials. The objective of the present study was to demonstrate the effect of two MW industrial frequency treatments on the microstructure and ultrastructure of Norway spruce and radiata pine wood.

\section{EXPERIMENTAL}

\section{Wood Material}

Wood of Norway spruce (Picea abies (L.) Karst.) and radiata pine (Pinus radiata D. Don) were studied. Sawn planks of Norway spruce with dimensions $45 \times 90 \times 2000 \mathrm{~mm}$ and initial moisture content (MC) of $60 \%$ were used in the experiments. The planks contained both sap- and heartwood, and the average oven dry density was $478 \mathrm{~kg} / \mathrm{m}^{3}$. Wood blocks of radiata pine $(90 \times 90 \times 2000 \mathrm{~mm})$ with an average initial MC of $40 \%$ and density of $480 \mathrm{~kg} / \mathrm{m}^{3}$ were used.

\section{Microwave Treatments}

The Norway spruce planks were MW treated in a $60 \mathrm{~kW}$ (two $30 \mathrm{~kW}$ generators from Muegge) microwave plant operating at a frequency $2.45 \mathrm{GHz}$, while radiata pine blocks were treated with $60 \mathrm{~kW}$ power at frequency of $0.922 \mathrm{GHz}$. The MW plant possesses four sub-systems:

1. A MW sub-system for efficient supply of MW energy to the timber includes generators with auto tuners and product specific MW applicators (i.e. a MW applicator is a device in which microwaves interact with the timber);

2. Conveyer for centring and moving the timber through the applicator at controllable speeds;

3. Air dynamic sub-system to remove water vapour and wood particles from the applicator and prevent moisture condensation on the internal surfaces of the applicator. It consists of a fan, an electric heater and a cyclone interconnected to the large-diameter air ducts;

4. Control and operation sub-system for effective control of the timber modification process. The technical specifications of the MW plant is shown in Table 1.

A three-port MW applicator with $2.45 \mathrm{GHz}$ frequency was used for experiments with Norway spruce (Fig. 1). For radiata pine processing, a one-port waveguide applicator at a frequency of $0.922 \mathrm{GHz}$ was used (Fig. 1). 
Table 1. Technical Specification of the MW Plant

\begin{tabular}{|c|c|c|}
\hline Parameters & \multicolumn{2}{|c|}{ Plant for treatment of sawn timber } \\
\hline Maximum timber size, $(\mathrm{mm})$ & $100 \times 100 \times 4500$ & $90 \times 90 \times 4500$ \\
\hline Frequency $(\mathrm{GHz})$ & 2.45 & 0.922 \\
\hline Max MW power, $(\mathrm{kW})$ & $2 \times 30$ & 60 \\
\hline Feed speed, $(\mathrm{m} / \mathrm{min})$ & up to 3 & up to 3 \\
\hline Air heater, $(\mathrm{kW})$ & 13 & 13 \\
\hline Fan, $(\mathrm{kW})$ & 2.8 & 2.8 \\
\hline Feed system & Rollers & Belt \\
\hline
\end{tabular}
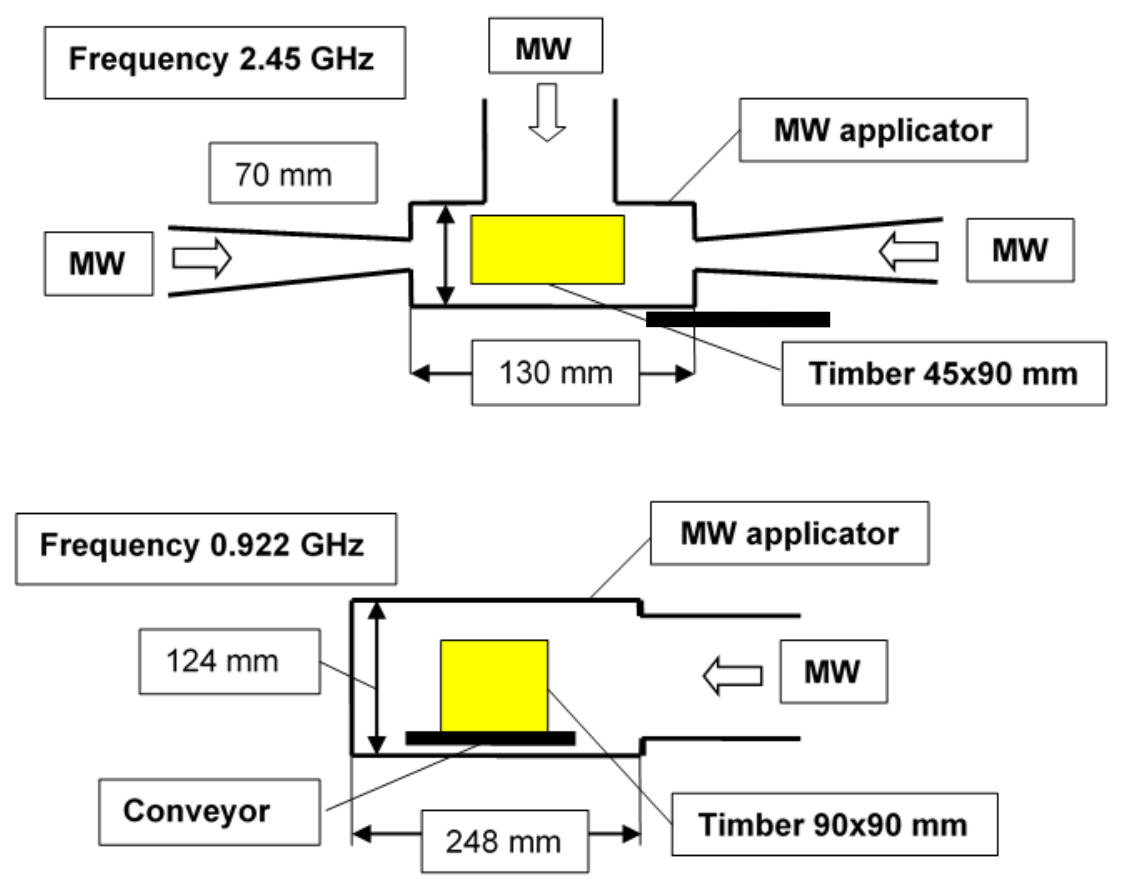

Fig. 1. Three-port MW applicator for $2.45 \mathrm{GHz}$ (top) and one-port $\mathrm{MW}$ applicator for $0.922 \mathrm{GHz}$ (bottom) frequency treatment of sawn timber

\section{Scanning Electron Microscopy (SEM)}

Changes in wood structure after MW modification were revealed using scanning electron microscopy. Wood samples were conditioned at $20{ }^{\circ} \mathrm{C}$ and relative humidity of $60 \%$. Thereafter, small sub-samples for microscopy (approximately $3 \times 3 \times 3 \mathrm{~mm}$ in radial (RLS), tangential (TS), tangential longitudinal (TLS), and radial (RLS) longitudinal direction) were cut from an area located $1 \mathrm{~mm}$ beneath the surface and another area located deeper in the plank. The sub-samples were planed carefully using a sledge microtome. They were then mounted on stubs using double-sided cellotape and coated with Pt/Pd using an on Agar High Resolution Sputter coater. Semi-thin sections (i.e., TS, TLS, RLS) were cut using a Leitz microtome, air-dried, mounted on stubs, and coated with gold (Emitech E5000 sputter coater) and observed using a Philips XL30 ESEM (FEI, Eindhoven, Holland, now ThermoFisher Scientific) at $15 \mathrm{kV}$ (Daniel et al. 2004). Features from the SEM observations were used to discuss the effect of $\mathrm{MW}$ on the anatomical features. 


\section{RESULTS AND DISCUSSION}

With the 3-port applicator $(2.45 \mathrm{GHz})$, the MW power was supplied by one generator via left and right radiators (50\% of total) and by a second generator via the top radiator (50\% of total). In the $0.922 \mathrm{GHz}$ applicator, all power was supplied from one generator. MW wood modification schedules used for wood processing are outlined in Table 2.

Table 2. MW Modification Schedules Used for Timber Processing

\begin{tabular}{|l|c|c|}
\hline \multicolumn{1}{|c|}{ Categories } & Norway spruce & Radiata pine \\
\hline Frequency, GHz & 2.45 & 0.922 \\
\hline MW power supplied, kW & 20 & 36 \\
\hline Timber speed in applicator, $\mathrm{mm} / \mathrm{s}$ & 17.3 & 12.1 \\
\hline MW energy absorbed by wood, $\mathrm{kWh} / \mathrm{m}^{3}$ & 79 & 102 \\
\hline $\begin{array}{l}\text { Average specific MW power supplied to the interaction } \\
\text { zone, W/cm }\end{array}$ & 25 & 22 \\
\hline
\end{tabular}

\section{MW Treatment Procedure}

The MW plant feeding system moves boards via MW applicator at required speeds. MW radiators supply MW energy to the board in the applicator from both the sides and top. Green wood readily absorbs microwave energy because of its high moisture content. This results in a very high release of energy from within the wood material. Intensive MW power applied to the wood generates steam pressure within wood cells. Under high internal pressure, the pit membranes in cell walls and weak ray cells are ruptured to form pathways for easy transportation of liquids and vapours. An increase in the intensity of the MW energy applied to the wood increases the internal pressure, resulting in the formation of cracks and voids in the radial-longitudinal planes (Fig. 2). Vapour released from the wood was removed from the applicator by an airflow with temperature of $110^{\circ} \mathrm{C}$.
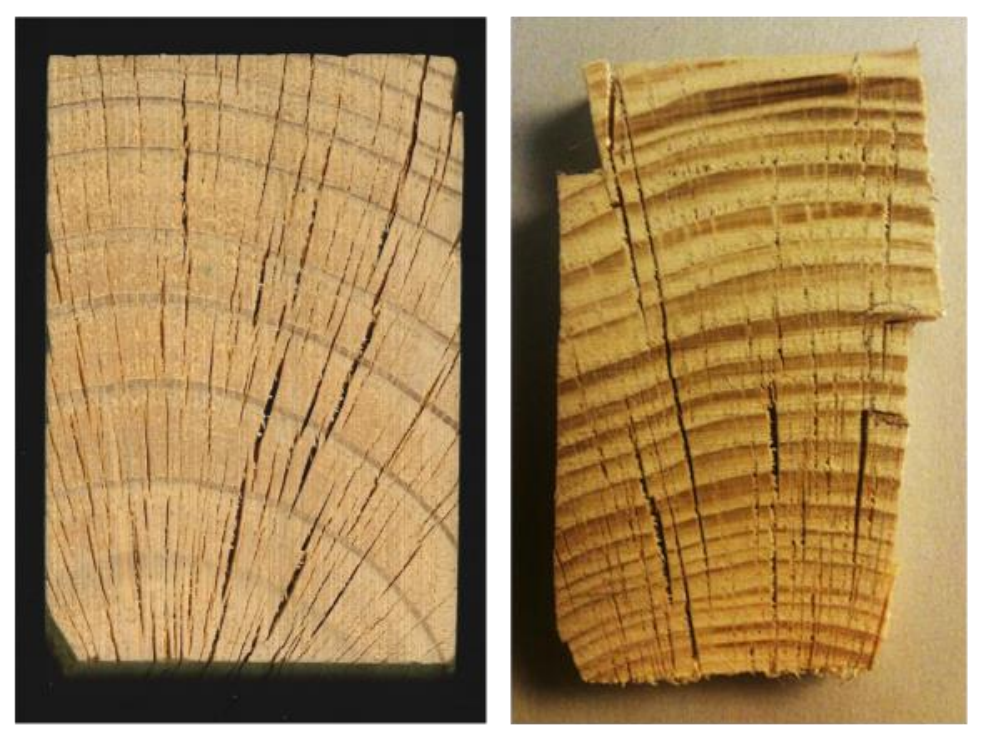

Fig. 2. Cross-sections of wood showing effect of intense microwave treatments on radiata pine (left) and spruce wood (right). Pronounced radial checking passes through several annual growth rings 
Softwood tracheids are connected by bordered pits, which are open in fresh undried sapwood. The pit's torus is suspended to the periphery of the pit chamber by a margo consisting of strands of cellulose microfibrils. MW heating inside moist wood is non-uniform and non-uniform water heating and evaporation creates pressure gradients between cells. "Hot spots" continually develop at different times and in different places in the wood, material. Chaotic "hot spots" provide local steam explosions in wood cells creating pressure gradients between cells that rupture pit membranes (i.e., torus and margo). Pressure gradients also rupture middle lamellae and cell walls if the applied MW power is very high.

\section{Microstructural Changes in Radiata Pine}

Although the microscopy study carried out cannot lead to any conclusions regarding the percentage of aspirated bordered pits, pit apertures in the MW treated wood often appeared modified (Fig. 3). Damage of pit apertures can facilitate the penetration of preservatives.

Major changes in the warty- and $\mathrm{S}_{3}$ layers of wood cells were apparent. These two fine layers are usually not considered as important structures due to their relatively small thickness compared to the $S_{2}$ layer. However, the warty and $S_{3}$ layers are of vital importance for the living tree, where they influence the transport process of sap; the collapse and checking of the cell wall starts from these layers when the sap is evacuated during drying. The two layers become extremely important during the process of impregnation since the majority of chemicals impregnated normally enter the wood cell wall through the warty- and $S_{3}$ layers. The concentration of lignin in the $S_{3}$ layer for some species is almost twice as high as in the $S_{2}$ layer (Donaldson 1987), thus providing better thermoplasticity and reduced cell wall porosity.
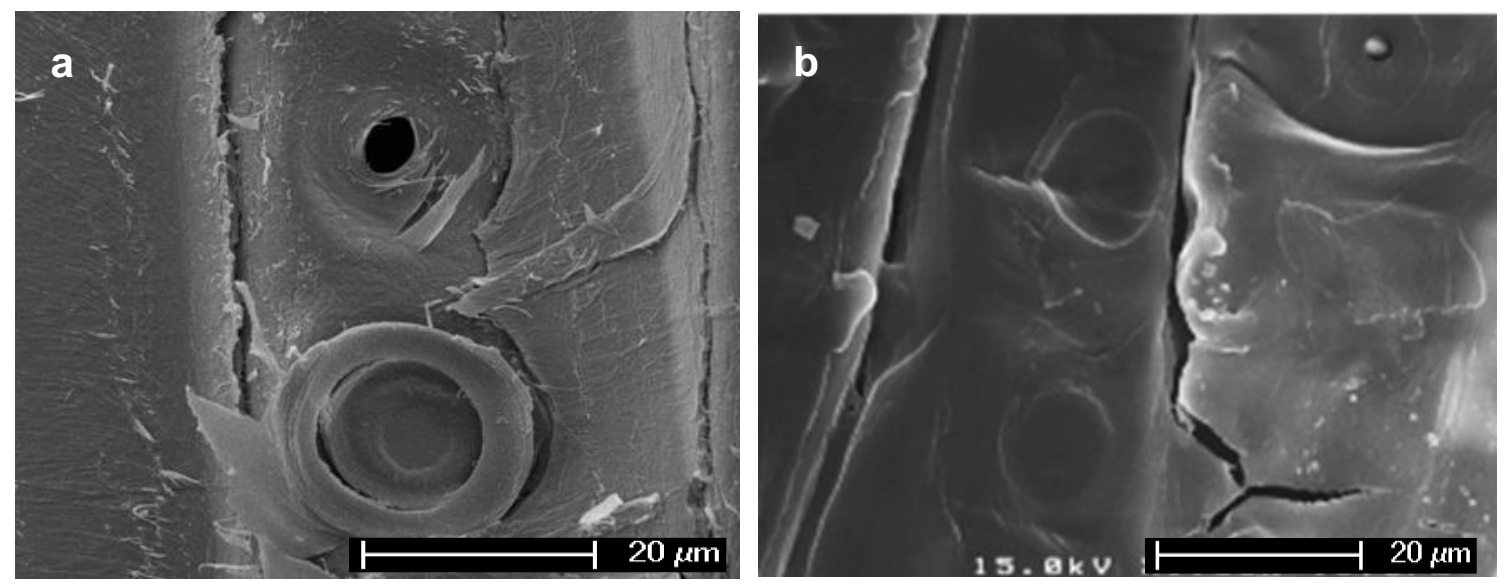

Fig. 3. Remains of pit apertures (left) after splitting and micro checks in $\mathrm{S}_{3}$ cell wall of radiata pine earlywood tracheids treated by microwaves (right)

SEM observations (Fig. 3) showed characteristic micro-checks in the $\mathrm{S}_{3}$ layer of MW treated samples. The micro-checks were approximately 1 to $2 \mu \mathrm{m}$ wide, appearing in a disorderly manner (Fig. 3) without any tendency to follow the microfibril angle of the $\mathrm{S}_{3}$ layer. Some micrographs show that certain places in the wood were normal without any visible changes and the pits appeared undamaged. In other places, numerous checks in the bordered pits were apparent (Fig. 2, left). The checks followed often along the pit aperture and continued in the $S_{2}$ layer. Remains of pit aperture after splitting are shown in Fig. 3 
(left) as evidence of the force of water vapour. The checks comprise the entire scale from wider than $1 \mathrm{~mm}$ macro checks to micro checks ( 1 to $2 \mu \mathrm{m}$ ) in the warty and $\mathrm{S}_{3}$ layers of the cell walls (Fig. 3, right).

The most common way of checking caused by MW treatment was along the rays (Fig. 2). The compound middle lamellae is the weakest point in the cell wall structure and frequent cleavage was apparent. In some cases, all the cells in the ray can be destroyed (Fig. 4).
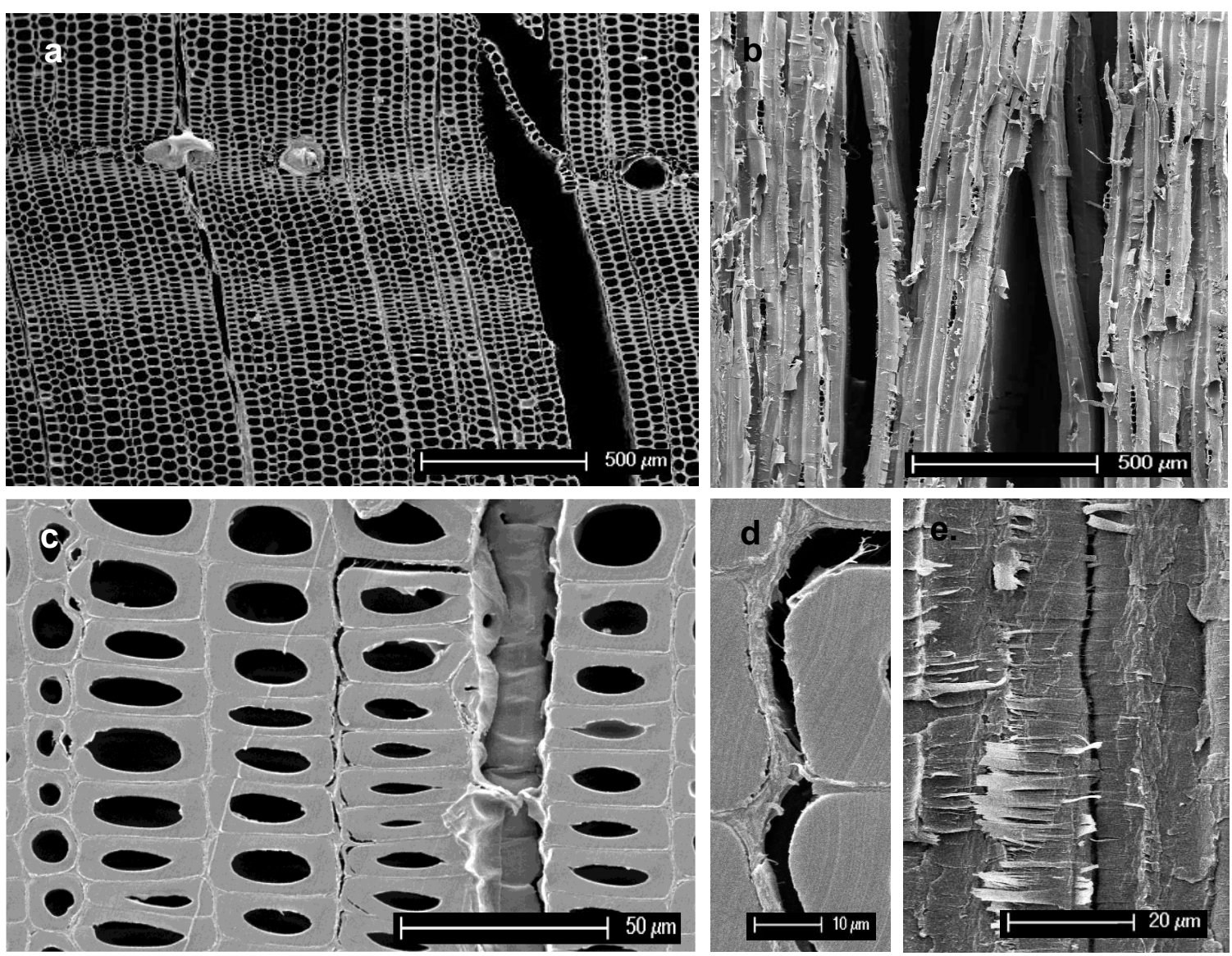

Fig. 4. SEM images of radiata pine after MW irradiation. a) TS section showing loss of tracheid integrity and fractures in ray canals; b) TLS section with longitudinal ruptures between separated tracheids; c, d) TS section of latewood with cracks formed along the radial and tangential walls of tracheids in middle lamella/primary wall regions; e) RLS showing ruptures along middle lamella/primary wall regions. Parts of the radial oriented S1 layer are also apparent

Ray cell walls are normally weaker than tracheids walls, and therefore almost all ray cells are ruptured after intensive MW treatment. Ray cell wall rupturing provides an increase of wood permeability mainly in radial direction and thus, the wood strength reduction caused by MW treatment can be explained by compound middle lamella weakening and/or rupturing, ray cell collapse and check development in the wood structure at both micro- and macro levels.

A high degree of MW modification converts wood into a highly porous material with numerous cavities, mainly in the radial-longitudinal planes and dramatically changes the physical and mechanical properties of wood. Checks present in the modified softwoods increases the specific wood volume up to $10 \%$ and accordingly reduces wood density. Up 
to a 4- to 5-fold increase in water uptake of wood relates to a dramatic increase in softwood permeability.

Summarising the results of the study on the radiata pine wood, it is concluded that some of the pit apertures of the MW treated material are torn, which probably contributes to overall easier total penetration of liquids into the wood. There are micro checks in the range of 1 to $2 \mu \mathrm{m}$, which provide direct access to the $S_{2}$ layer in the treated wood. Very fine nano checks (10 to $20 \mathrm{~nm}$ ) are found in the warty and $S_{3}$ layers. Checks in the MW treated wood follow the rays and are wider $(1 \mu \mathrm{m}$ to $1 \mathrm{~mm})$.

\section{Micro Structural of Wood Structure in Norway Spruce}

Observations on irradiated Norway spruce samples showed that at least part of the high frequency energy was concentrated in the compound middle lamellae regions between tracheids, which showed considerable disruption while the tracheid wall structure appeared relatively undamaged (Fig. 5).
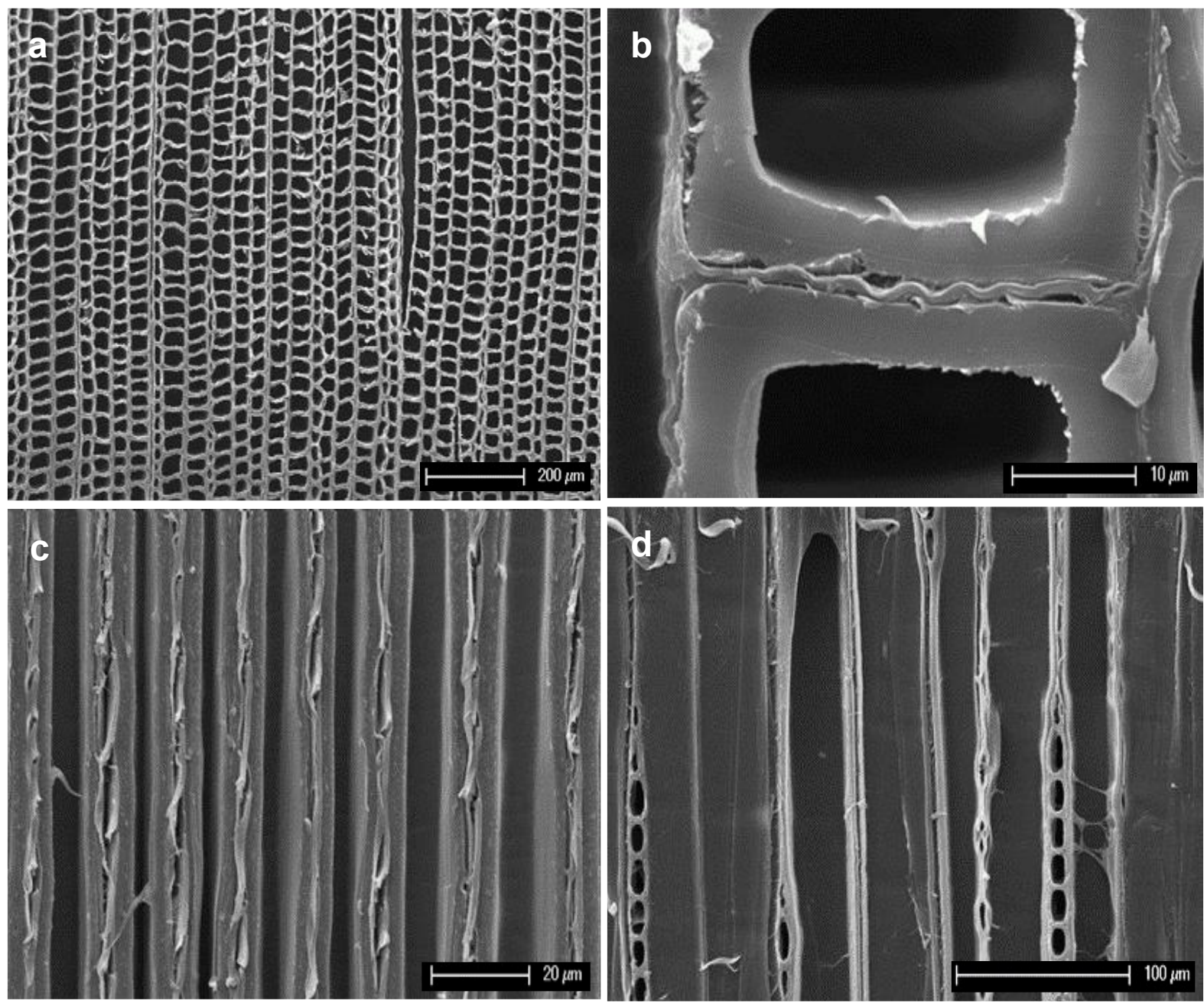

Fig. 5. SEM images of fresh spruce after MW irradiation. a) TS section showing a general loss of tracheid integrity and fractures in the ray canals; b) TS section of latewood tracheid showing modification of the compound middle lamellae between adjacent tracheids; c) RLS sections showing disruption of the middle lamella regions between axial tracheids; d) TLS section with ruptures in the middle lamellae regions between axial tracheids and ray/tracheid interphases 
Severe checks along the rays comparable with radiata pine were the most obvious checking due to microwave treatment in spruce. The compound middle lamella is the weakest point in the cell wall, and cleavage occurs usually there. The above-mentioned structural changes facilitated the penetration of the preservative during impregnation but also decreased the mechanical properties after the microwave treatment. The density of wood decreased progressively with increased duration of the treatment contributing to a lower strength of the treated wood. The observed changes are proportional to the applied power and duration of treatment. Figures $5 \mathrm{~b}$ and $5 \mathrm{c}$ demonstrate distinct buckling and weakening of compound middle lamella regions between tracheids in late- and earlywood of Norway spruce. Microwave irradiation treatment causes lignin depolymerisation (Scott et al. 2002). Another study of the effect of temperature and microwaves on lignin and hemicelluloses (Arshanitsa et al. 2016) showed that MW treatment also leads to decomposition and partial destruction of the chemical bonds between the wood main structural polymers.

In a previous study using low intensity MW hardwood treatment, He et al. (2017) showed that the shape of the ray cells observed in the tangential-longitudinal direction of wood remained the same, but that vessel tyloses were torn and/or totally destroyed and minor cracks developed in middle lamella regions. Pit membranes observed in the radiallongitudinal direction of the hardwood also appeared damaged after microwave irradiation. The MW treatment increased wood permeability twice as much compared untreated samples. In the present study, the high intensity MW modification used resulted in similar morphological changes of ray cells, pit membranes, and middle lamellae of the cell wall, implying a significant increase in wood permeability of spruce and radiata pine as indicated by the macrostructural changes (Fig. 2).

\section{CONCLUSIONS}

1. MW treatment caused severe check development along the rays, with the wood density and mechanical features influenced negatively in both radiata pine and Norway spruce. The most probable way of checking due to microwave treatment is along the rays.

2. The compound middle lamellae are the weakest regions in the cell wall, and frequent cleavage in this region was apparent. In some cases, all the parenchyma cells in the rays were disrupted. It is expected that the temperature and microwave irradiation on lignin and hemicelluloses affect decomposition and bond destruction between cellulose and lignin and between cellulose and hemicelluloses.

3. Some irregular checking in the bordered pits was observed. The checks often followed along the pit aperture and continued into the $S_{2}$ layer. The development of checks comprised the entire scale from wider than $1 \mathrm{~mm}$ macro checks to micro-checks (1 to 2 $\mu \mathrm{m})$ in the warty and $S_{3}$ layers of the cell walls.

4. Microwave destruction of different wood structure elements provides an increase in wood permeability for liquids and gases. By governing the applied energy, a better control on the degree of wood modification and permeability increase required for practical MW technology use can be achieved. Knowledge of the effects of MW treatment on wood structure allows assessment of the opportunities for microwave use in wood technology. 


\section{ACKNOWLEDGMENTS}

The authors thank the financial support granted by the Swedish Research Council for Sustainable Development (FORMAS), to the project "Exploring microwave technology for energy efficient mechanical pulping and increased permeability of spruce wood," grant number 2014-6383-27292-77.

\section{REFERENCES CITED}

Arshanitsa, A., Dizhbite, T., Bikovens, O., Pavlovich, G., Andersone, A., and Telysheva, G. (2016). "Effects of microwave treatment on the chemical structure of lignocarbohydrate matrix of softwood and hardwood," Energy \& Fuels 30(1), 457464. DOI: $10.1021 /$ acs.energyfuels.5b02462

Antti, A. (1999). Heating and Drying Wood using Microwave Power, Ph.D. Dissertation, Luleå University of Technology, Skellefteå, Sweden.

Antti, A. L., and Perré, P. (1999). "A microwave applicator for on-line wood drying: Temperature and moisture distribution in wood," Wood Science and Technology 33, 123-138. DOI: $10.1007 / \mathrm{s} 002260050104$

Avramidis, S., Zwick, R. L., and Neilson, B. J. (1994). "Commercial scale RF/V drying of softwoods. Part I. Basic kiln design considerations," Forest Products Journal 46(5), 44-51.

Avramidis, S., and Zwick, R. L. (1994). "Commercial scale RF/V drying of softwoods. Part II. Drying characteristics and degrade," Forest Products Journal 46(6), 27-36.

Daniel, G., Duchesne, I., Tokoh, C., and Bardage, S. (2004). "The surface and intracellular nanostructure of wood fibres: Electron microscope methods and observations," in: Proceedings of COST Action: Wood Fibre Cell Walls: Methods to Study Their Formation, Structure and Properties, Uppsala, Sweden, pp. 87-104.

Donaldson, L. A. (1987). "S3 lignin concentration in radiata pine tracheids," Wood Science and Technology 21, 227-234.

Hansson, L. (2007). Microwave Treatment of Wood, Ph.D. Dissertation, Luleå University of Technology, Skellefteå, Sweden.

He, X., Xiong, X., Xie, J., Li, Y., Wei, Y., Quan, P., Mou, Q., and Li, X. (2017). "Effect of microwave pre-treatment on permeability and drying properties of wood," BioResources 12(2), 3850-3863.

Leiker, M., and Adamska, M. (2004). "Energy efficiency and drying rates during vacuum microwave drying of wood," Holz als Roh- und Werkstoff 62, 203-208.

Liu, H.-H., Wang, Q.-W., Yang, L., and Cai, Y.-C. (2005). "Modification of larch wood by intensive microwave irradiation," Journal of Forestry Research 16 (3), 237-240. DOI: $10.1007 / \mathrm{BF} 02856823$

Oloyede, A., and Groombridge, P. (2000). "The influence of microwave heating on mechanical properties of wood," Journal of Material Processing Technology 100, 6773. DOI: 10.1016/S0924-0136(99)00454-9

Perré, P., and Turner, I. W. (1999). "The use of numerical simulation as a cognitive tool for studying the microwave drying of softwood in an over-sized waveguide," Wood Science and Technology 33(6), 445-464. DOI: 10.1007/s002260050129

Perré, P., and Turner, I. W. (2004). "Environmental and energy engineering microwave drying of softwood in an oversized waveguide: Theory and experiment," AIChE 
Journal 43(10), 2579-2595. DOI: 10.1002/aic.690431019

Scott, C., Klungness, J., Lentz, M., Horn, E., and Akhtar, M. (2002). "Microwaving logs for energy savings and improved paper properties for mechanical pulps," in: Proceedings TAPPI Fall Conference and Trade Fair, San Diego, USA, pp. 1-10.

Treu, A., and Gjølsjø, S. (2008). "Spruce impregnation, finally a breakthrough by means of microwave radiation?," in: Proceedings $4^{\text {th }}$ Meeting of the Nordic Baltic Network in Wood Material Science \& Engineering (WSE), Riga, Latvia, pp. 42-48.

Torgovnikov, G. I. (1993). Dielectric Properties of Wood and Wood-Based Materials, New York, Springer-Verlag.

Torgovnikov, G., and Vinden, P. (2000). "New wood based materials Torgvin and Vintorg," in: Proceedings $5^{\text {th }}$ Pacific Rim Bio-Based Composite Symposium, Canberra, Australia, pp. 756-764.

Torgovnikov, G., and Vinden, P. (2009). "High intensity microwave wood modification for increasing permeability," Forest Products Journal 59(4), 84-92.

Zhao, H., and Turner, I. W. (2000). "The use of a coupled computational model for studying the microwave heating of wood," Applied Mathematical Modeling 24, 183197. DOI: $10.1016 / \mathrm{S} 0307-904 \mathrm{X}(99) 00034-7$

Article submitted: April 3, 2020; Peer review completed: May 16, 2020; Revised version received and accepted: May 22, 2020; Published: May 29, 2020.

DOI: 10.15376/biores.15.3.5616-5626 